\title{
HEVOSTEN KARVOJEN KALSIUM-, MAGNESIUM-, NATRIUM-, KALIUM-, SINKKI-, RAUTA-, KUPARI- JA MANGAANIPITOISUUKSIEN VAIHTELUISTA
}

\author{
Vappu Kossila, Erkki Virtanen, Hilkka Hakatie ja Esko Luoma \\ Helsingin yliopiston kotieläintieteen laitos
}

Saapunut 12. 9. 1972

\begin{abstract}
CALCIUM, MAGNESIUM, SODIUM, POTASSIUM, ZINC, IRON, COPPER AND MANGAN IN THE HAIR AND THE MANE OF THE HORSES

Vappu Kossila, Erkki Virtanen, Hilkka Hakatie and Esko Luoma

Department of Animal Husbandry, University of Helsinki
\end{abstract}

\begin{abstract}
Contents of calcium, magnesium, sodium, potassium, iron, copper, zinc, mangan and ash in the hair samples, obtained from the neck of white (VA), sorrell (RA), bay (RU) and dark bay + black (TU) horses were analyzed in March (III), June (VI), September (IX) and January (I). Composition of the hair in relation to that in the mane was also studied in $\mathbf{I}$.

Seasonal variations were found in all constituents studied. Highest $\mathrm{Ca}, \mathrm{Mg}$ and $\mathrm{K}$ were obtained in IX, $\mathrm{Zn}$ and $\mathrm{Fe}$ in VI and $\mathrm{Cu}$ in $\mathrm{I} . \mathrm{Ca}, \mathrm{Na}, \mathrm{K}$ and ash were low in I, $\mathrm{Zn}$ and $\mathrm{Fe}$ in $\mathrm{I}$ and $\mathrm{III}$, and $\mathrm{Cu}$ and $\mathrm{Mn}$ in VI.

Hair composition was influenced by the color of the hair the contents of $\mathrm{Ca}, \mathrm{Mg}, \mathrm{Na}$, $\mathrm{K}, \mathrm{Cu}, \mathrm{Mn}$ and ash being higher in TU and RU than in RA or VA.

More $\mathrm{Ca}, \mathrm{Mg}, \mathrm{Na}, \mathrm{K}$ and ash but less $\mathrm{Zn}$ and $\mathrm{Cu}$ were found in black than in white mane. Within the four color groups of horses the mane contained much less $\mathrm{Ca}$ and somewhat less $\mathrm{Fe}$ but somewhat more $\mathrm{Na}, \mathrm{K}$ and $\mathrm{Cu}$ than the hair of the horses.
\end{abstract}

Viimeaikaiset eri maissa suoritetut tutkimukset ovat osoittaneet, että karvojen kivennäis- ja hivenainepitoisuuksien perusteella voidaan saada selville eräitä eläinten kivennäis- ja hivenaineiden puutostiloja. Kotieläinten karvatutkimuksia on tähän mennessä suoritettu ehkä eniten märehtijöillä, nim. naudalla, vuohella ja lampaalla (ANKE 1971). Niistä on käynyt ilmi, että ravitsemustekijöiden lisäksi karvan väri, laatu, leikkauskohta ja syvyys, vuodenaika sekä eläimen ikä, rotu ja geneettiset tekijät vaikuttavat tuloksiin. ANken mukaan lypsylehmien ja siitossikojen karvojen fosfori-, natrium-, sinkki-, mangaani-, kupari- ja molybdeenipitoisuuksista voidaan päätellä, missä määrin eläimet ovat saaneet ravinnossaan näitä elementtejä.

Goss ja GreEN (1952) ovat havainneet värin vaikuttavan hevosen karvojen kuparipitoisuuteen. KowNAcKI (1962) totesi maaperän kivennäis- ja hivenainepitoisuuksien vaikuttavan työhevosten karvojen koostumukseen. SIPPEL et al. (1964) tutkivat vuodenajan ja iän vaikutusta karvojen kivennäis- ja hivenainepitoisuuksiin täysverihevosilla todeten mm., että rautaa lukuunottamatta pikkuvarsojen karvoissa oli korkeammat ki- 
vennäis- ja hivenainemäärät kuin täyskasvuisilla hevosilla. Wysocki ja KLETT (1971) suorittivat tutkimuksia ravinnon kalsium- ja fosforipitoisuuksien vaikutuksista ponivarsojen karvojen koostumukseen.

ANKen (1971) mukaan värillinen peitinkarva soveltuu parhaiten naudan kivennäisja hivenainepuutosten indikaattoriksi. O'MARYn et al. (1970) mukaan valkoinen karva soveltuu paremmin ainakin Cu-puutoksen indikaattoriksi kuin värillinen. Hevoset ovat yleensä yksivärisiä lukuunottamatta sukkia tms. peitinkarvan värin vaihdellessa valkoisesta mustaan, kun taas naudat ovat varsin usein kaksivärisiä. Hevosten karvat ovat lämpimänä vuodenaikana sitäpaitsi niin lyhyet, että karvaa joudutaan leikkaamaan varsin laajalta alueelta riittävän karvamäärän saamiseksi analyysiä varten.

Tässä tutkimuksessa on pyritty selvittämään, missä määrin hevosen väri ja näytteenottokuukausi vaikuttavat peitinkarvojen kivennäis- ja hivenainepitoisuuksiin sekä miten peitinkarvojen ja harjajouhien koostumukset poikkeavat toisistaan.

\section{Aineisto ja menetelmät}

Karvanäytteet kerättiin maalis-, kesä-, syys- ja tammikuussa vv. 1971/72 Tuomarinkylän Ratsastuskoulun tallissa pidetyistä hevosista. Näytteet leikattiin esteettisistä syistä yleensä harjan alta, leikkuukorkeuden ollessa noin $1 \mathrm{~mm}$ ihonpinnasta. Koska kesä- ja syyskuussa muutamilla hevosilla karva oli hyvin lyhyttä, jouduttiin niiltä leikkaamaan karvaa laajemmalta alueelta kaulasta rïttävän suuren karvanäytteen saamiseksi.

Noin 1-1.5 gramman karvanäyteessä uutettiin 1 tunti eetterillä, minkä jälkeen näyte pestiin kuumalla ioninvaihtovedellä (ref. ANKE 1965). Kuiva-aineen määrittämiseksi näytteitä kuivattiin yli yön $100^{\circ} \mathrm{C}$ :ssa. Tuhkamäärityksiä varten näytteet poltettiin $550^{\circ} \mathrm{C}$ :ssa $24 \mathrm{t}$. Tuhka liuotettiin $2 \mathrm{ml}$ :aan conc. $\mathrm{HCl}$, haihdutettiin vesihauteessa kuiviin, liuotettiin $2 \mathrm{ml}$ :aan $2.5-\mathrm{N} \mathrm{HCl}$ ja suodatettiin Whatman no. 4 suodatinpaperin läpi kvantitatiivisesti $50 \mathrm{ml}: \mathrm{n}$ mittapulloon. Kationit määritettiin Varian Techtron AA-1000 spektrofotometrillä.

Suurin osa tutkituista hevosista oli Tanskasta ostettuja puoliverihevosia. Hevosista 18 oli ruunia, joukossa 1 suomenhevonen sekä 1 Islanninponi ja 7 oli tammoja, joukossa 1 täysverienglantilainen. Hevosten ikä vaihteli 5-23 vuoden välillä. Tulosten käsittelyä varten hevoset jaettiin neljään ryhmään värin mukaan: 1. tummat ruunikot ja mustat (musta harja), 2. ruskeat ruunikot (musta harja), 3. raudikot (ruskea harja) ja 4. vaaleat hevoset, joiden peitinkarvan dominoiva väri oli selvästi valkoinen. Vm. hevosia oli kaikkiaan kuusi; kahdella niistä oli jonkin verran ruskeita karvoja valkeiden peitinkarvojen joukossa ja vaalean punaruskeat harjajouhet; yksi oli lähes valkoinen kimo; yksi ns. Knabstrupin hevonen, jolla oli vartalossa ja kaulassa tummia läiskiä vaalealla pohjalla ja harja kuin kimolla; yksi oli kokonaan valkea; yksi oli pinto, jonka pääväri oli valkea, mutta jonka vartalossa, kaulassa ja päässä oli ruskeakarvaisia alueita ja jonka harjajouhet olivat osittain valkeat, osittain mustat.

\section{Tulokset}

Tutkittujen näytteiden kivennäis- ja hivenainepitoisuudet vaihtelivat huomattavan laajoissa rajoissa. Taulukossa 1 on esitetty minimi- ja maksimiarvot väriryhmittäin otta- 
Taulukko 1. Hevosten peitinkarvojen minimi ja maksimi kivennäis- ja hivenainemäärät väriryhmittäin. Table 1. Range values of the minerals and trace elements in the hair of the horses in the different color groups.

\begin{tabular}{ccccc}
\hline & $\begin{array}{c}\text { Mustat ja } \\
\text { tummat }(\mathrm{TU}) * \\
\mathrm{~N}=21\end{array}$ & $\begin{array}{c}\text { Ruunikot } \\
(\mathrm{RU})^{*} \\
\mathrm{~N}=26\end{array}$ & $\begin{array}{c}\text { Raudikot } \\
(\mathrm{RA})^{*} \\
\mathrm{~N}=14\end{array}$ & $\begin{array}{c}\text { Vaaleat } \\
(\mathrm{VA})^{*}\end{array}$ \\
$\mathrm{~N}=28$
\end{tabular}

* see the footnotes of Table 2.

$\mathrm{N}=$ näytteiden lukumäärä; $\mathbf{N}=$ number of cases

Taulukko 2. Samoilta hevosilta toistuvasti eri kuukausina analysoidut peitinkarvojen kivennäis- ja hivenainepitoisuudet väriryhmittäin.

Table 2. Mineral and trace element contents in the hair of the same horses according to the month of the year and the color of the hair.

\begin{tabular}{|c|c|c|c|c|c|c|c|c|c|c|c|}
\hline \multirow{2}{*}{$\begin{array}{l}\text { Kuukausi } \\
\text { Month }\end{array}$} & \multirow{2}{*}{$\begin{array}{l}\text { Väri } \\
\text { Color }\end{array}$} & \multicolumn{9}{|c|}{ ppm } & \multirow{2}{*}{$\begin{array}{r}\text { Tuhka- } \% \\
\text { Ash- } \%\end{array}$} \\
\hline & & $\mathrm{N}$ & $\mathrm{Ca}$ & $\mathrm{Mg}$ & $\mathrm{Na}$ & $\mathrm{K}$ & $\mathrm{Zn}$ & $\mathrm{Fe}$ & $\mathrm{Cu}$ & Mn & \\
\hline Maalis & $\mathrm{TU}$ & 3 & 1472 & 340 & 317 & 221 & 118 & 54 & 9.6 & 4.6 & 1.45 \\
\hline \multirow[t]{3}{*}{ March } & $\mathrm{RU}$ & 3 & 1555 & 283 & 232 & 85 & 135 & 56 & 12.1 & 4.9 & 1.06 \\
\hline & RA & 2 & 707 & 145 & 163 & 41 & 135 & 36 & 11.8 & 2.4 & 0.67 \\
\hline & VA & 5 & 423 & 83 & 130 & 49 & 140 & 33 & 9.1 & 2.7 & 0.54 \\
\hline Kesä & TU & 3 & 1301 & 333 & 211 & 172 & 188 & 124 & 7.7 & 1.8 & 1.48 \\
\hline \multirow[t]{3}{*}{ June } & $\mathrm{RU}$ & 3 & 962 & 218 & 132 & 105 & 185 & 141 & 13.0 & 1.6 & 1.44 \\
\hline & RA & 2 & 787 & 195 & 243 & 139 & 244 & 109 & 7.8 & 1.6 & 1.02 \\
\hline & VA & 5 & 480 & 113 & 153 & 94 & 171 & 144 & 8.4 & 1.3 & 0.78 \\
\hline Syys & TU & 3 & 1739 & 305 & 177 & 174 & 148 & 73 & 11.8 & 1.9 & - \\
\hline \multirow[t]{3}{*}{ September } & $\mathrm{RU}$ & 3 & 1733 & 345 & 202 & 192 & 166 & 97 & 9.0 & 3.8 & - \\
\hline & RA & 2 & 737 & 239 & 125 & 188 & 162 & 87 & 7.7 & 2.6 & - \\
\hline & VA & 5 & 734 & 140 & 297 & 270 & 162 & 91 & 10.9 & 1.8 & - \\
\hline Tammi & $\mathrm{TU}$ & 3 & 1224 & 358 & 56 & 46 & 138 & 44 & 10.7 & - & 0.95 \\
\hline \multirow[t]{3}{*}{ January } & $\mathrm{RU}$ & 3 & 1066 & 177 & 55 & 37 & 143 & 65 & 18.3 & - & 0.82 \\
\hline & RA & 2 & 672 & 197 & 61 & 65 & 146 & 50 & 11.3 & - & 0.33 \\
\hline & VA & 5 & 167 & 75 & 54 & 22 & 143 & 70 & 14.4 & - & 0.22 \\
\hline
\end{tabular}

$\mathrm{TU}=$ tummat ruunikot ja mustat ( 2 tammaa, 1 ruuna); $\mathrm{TU}=$ dark bay and black ( 2 mares, 1 gelding $).$

$\mathrm{RU}=$ punaruunikot $(3$ ruunaa); $\mathrm{RU}=$ bay (3 geldings).

$\mathrm{RA}=$ raudikot $(1$ tamma, 1 ruuna $) ; \mathrm{RA}=$ sorrell $(1$ mare, 1 gelding $)$.

$\mathrm{VA}=$ vaaleat $(1$ tamma, 4 ruunaa); $\mathrm{VA}=$ white $(1$ mare, 4 geldings $)$.

$\mathrm{N}=$ hevosten lukumäärä; $\mathrm{N}=$ number of horses. 
Taulukko 3. Hevosten peitinkarvojen kivennäis- ja hivenainepitoisuudet näytteenottokuukausittain. Table 3. Effect of the sampling month on the mineral and trace element contents in the hair of the horses.

\begin{tabular}{lcccccccccc}
\hline $\begin{array}{l}\text { Näytteenottokk. } \\
\text { Month }\end{array}$ & N & Ca & Mg & Na & K & Zn & Fe & Cu & Mn & \multicolumn{1}{c}{ Ash-\% } \\
\hline Maalis & a 13 & 1039 & 213 & 211 & 99 & 132 & 45 & 10.7 & 3.7 & 0.93 \\
March & b 17 & 1003 & 204 & 234 & 104 & 138 & 49 & 10.2 & 3.2 & 0.91 \\
\hline Kesä & a 13 & 882 & 215 & 186 & 128 & 197 & 130 & 9.2 & 1.6 & 1.18 \\
June & b 17 & 882 & 211 & 214 & 162 & 186 & 132 & 9.5 & 1.6 & 1.26 \\
\hline Syys & a 13 & 1236 & 257 & 200 & 206 & 160 & 87 & 9.9 & 2.5 & - \\
September & b 20 & 1207 & 244 & 218 & 197 & 163 & 77 & 10.6 & 2.5 & - \\
\hline Tammi & a 13 & 782 & 202 & 57 & 43 & 142 & 57 & 13.7 & - & 0.58 \\
Jamuary & b 23 & 768 & 201 & 60 & 32 & 143 & 57 & 13.2 & - & 0.57 \\
\hline
\end{tabular}

$\mathrm{a}=13: \mathrm{n}$ hevosen näytteet; $\mathrm{a}=$ samples from the same 13 horses.

$\mathrm{b}=$ kaikki tutkitut näytteet; $\mathbf{b}=$ samples from all horses.

$\mathrm{N}=$ hevosten lukumäärä; $\mathrm{N}=$ number of horses.

matta huomioon näytteenottokuukauden vaikutusta. Taulukon 1 arvoissa värin vaikutus käy ilmi lähinnä vain Ca:n ja Mg:n sekä tuhkan kohdalla, joiden pitoisuudet pienenevät tummista vaaleisiin karvoihin.

Värin ja vuodenajan merkitys. Kolmentoista hevosen karvanäytteet kerättiin neljästi. Eri näytteenottokuukausina näistä eri väriryhmille saadut peitinkarvan keskim. kivennäis- ja hivenainepitoisuudet on esitetty Taulukossa 2. Siitä käy ilmi, että tummien peitinkarvojen Ca-, Mg- ja tuhkapitoisuudet ovat korkeimmat ja vaaleiden alhaisimmat. Na:n, K:n, Zn:n, Fe:n ja Cu:n kohdalla värin vaikutus ei käy Taulukosta 2 selvästi ilmi. Mn:ää on tummien sekä punaruunikkohevosten karvoissa ollut enemmän kuin raudikoiden ja vaaleiden hevosten karvoissa.

Peitinkarvojen kivennäis- ja hivenainepitoisuuksissa ilmeni myös vuodenaikaisvaihteluita (Taulukot 2 ja 3). Taulukossa 3 on esitetty väriryhmillä painotetut kivennäisja hivenainepitoisuuksien keskiarvot näytteenottokuukausittain erikseen a) em. 13 hevosella sekä b) kaikilla tutkituilla hevosilla. Taulukosta 3 käy ensinnäkin ilmi, että aja b-arvot ovat olleet hyvin samanlaiset tietyn näytteenottokuukauden kohdalla, joten saman hevosen mukanaolo eri näytteenottokertoina ei ole välttämätöntä. Taulukosta 3 käy lisäksi ilmi, että karvojen Ca-pitoisuus oli korkein syyskuussa mutta alhaisin tammikuussa; Mg-pitoisuus vaihteli vähemmän, maksimiarvot mitattiin syyskuussa. Karvojen Na-pitoisuus oli alhaisin tammikuussa, muina kuukausina pitoisuus oli keskim. noin 200 ppm. Kaliumia oli karvoissa eniten syyskuussa ja vähiten tammikuussa. Zn- ja Fe-arvot olivat korkeita kesäkuussa mutta alhaisia tammi- ja maaliskuussa. Kuparia oli karvoissa eniten tammikuussa ja vähiten kesäkuussa. Mn jäi määrittämättä tammikuun näytteistä; muina kuukausina tutkituissa karvoissa Mn-pitoisuus oli korkeimmillaan maaliskuussa. Tuhka jäi määrittämättä syyskuussa; tutkituista näytteistä tuhkaa oli eniten kesäkuussa.

Näytteenottokuukaudella painotetut kaikista tutkituista hevosista otettujen karvanäytteiden keskim. kivennäis- ja hivenainepitoisuudet on esitetty taulukossa 4 . Siitä käy 
Taulukko 4. Hevosen peitinkarvan kivennäis- ja hivenainepitoisuudet väriryhmittäin.

Table 4. Effect of color on the mineral and trace element contents in the hair of the horses.

\begin{tabular}{ccrrrrrrrrr}
\hline $\begin{array}{l}\text { Väriryhmä } \\
\text { Color group* }\end{array}$ & $\mathrm{N}$ & $\mathrm{Ca}$ & $\mathrm{Mg}$ & $\mathrm{Na}$ & $\mathrm{K}$ & $\mathrm{Zn}$ & $\mathrm{Fe}$ & $\mathrm{Cu}$ & $\mathrm{Mn}$ & \multicolumn{1}{c}{ Ash-\% } \\
\hline TU & 23 & 1382 & 319 & 247 & 184 & 154 & 78 & 10.5 & 2.5 & 1.25 \\
RU & 26 & 1284 & 262 & 183 & 127 & 161 & 85 & 14.2 & 3.1 & 1.15 \\
RA & 14 & 742 & 174 & 132 & 84 & 161 & 67 & 9.3 & 2.0 & 0.68 \\
VA & 28 & 452 & 105 & 164 & 106 & 153 & 83 & 10.3 & 1.9 & 0.53 \\
\hline
\end{tabular}

* see the footnotes of table 2.

$\mathrm{N}=$ näytteiden lukumäärä; $\mathrm{N}=$ number of samples

Taulukko 5. Hevosten peitinkarvojen ja harjajouhien kivennäis- ja hivenainepitoisuudet väriryhmittäin tammikuussa.

Table 5. Mineral and trace element contents in the hair and the mane of the different color groups of the horses in January.

\begin{tabular}{ccrrrrrrrrr}
\hline $\begin{array}{c}\text { Väriryhmä } \\
\text { Color group }\end{array}$ & & & \multicolumn{9}{c}{$\mathrm{ppm}$} & & & \multicolumn{2}{c}{ Tuhka-\% } \\
\hline \multirow{2}{*}{ TU } & $\mathrm{N}$ & 7 & 1191 & 342 & 70 & 48 & 141 & 48 & 12.6 & 0.889 \\
& $\mathrm{j}$ & 7 & 140 & 253 & 73 & 51 & 132 & 40 & 17.0 & 0.646 \\
\hline \multirow{2}{*}{$\mathrm{RU}$} & $\mathrm{k}$ & 6 & 1047 & 197 & 60 & 36 & 147 & 65 & 15.7 & 0.777 \\
& $\mathrm{j}$ & 6 & 122 & 241 & 83 & 42 & 143 & 34 & 15.9 & 0.583 \\
\hline \multirow{2}{*}{$\mathrm{RA}$} & $\mathrm{k}$ & 3 & 649 & 188 & 57 & 23 & 143 & 49 & 10.8 & 0.367 \\
& $\mathrm{j}$ & 3 & 104 & 231 & 71 & 25 & 146 & 43 & 14.6 & 0.480 \\
\hline \multirow{2}{*}{$\mathrm{VA}$} & $\mathrm{k}$ & 6 & 183 & 77 & 52 & 21 & 141 & 66 & 13.5 & 0.232 \\
& $\mathrm{j}$ & 6 & 48 & 78 & 56 & 22 & 151 & 38 & 29.4 & 0.340 \\
\hline
\end{tabular}

* see the footnotes of Table 2.

$\mathbf{k}=$ peitinkarva; $\mathbf{k}=$ hair.

$\mathrm{j}=$ harjajouhet; $\mathrm{j}=$ mane

$\mathrm{N}=$ hevosten lukumäärä; $\mathrm{N}=$ number of horses.

ilmi, että väri vaikuttaa paitsi Ca-, $\mathrm{Mg}$ - ja tuhka-, myös $\mathrm{Na}-, \mathrm{K}-$ ja jonkinverran $\mathrm{Cu}-$ ja Mn-määriin korkeimpien pitoisuuksien ollessa tummissa ja alhaisimpien vaaleissa peitinkarvoissa. Sen sijaan Zn- ja Fe-määriin väri ei ole vaikuttanut.

Peitinkarvat verrattuina harjajouhiin. Tammikuussa otettiin 22 hevoselta näytteet tutkittaviksi samanaikaisesti sekä peitinkarvasta että harjajouhista. Yhteenveto analyysituloksista on esitetty taulukossa 5. Siitä käy ilmi, että peitinkarvan Ca-pitoisuus on ollut kaikissa väriryhmissä erittäin selvästi suurempi kuin harjajouhissa ja että tummissa ja ruskeissa harjajouhissa on ollut enemmän kalsiumia kuin vaaleissa.

Tummakarvaisimpien hevosten ryhmässä (TU) peitinkarvan Mg-pitoisuus oli korkeampi kuin harjajouhien; muiden väriryhmien sisällä peitinkarvojen Mg-pitoisuus oli samaa suuruusluokkaa tai pienempi kuin harjajouhissa. Mustissa harjajouhissa oli enemmän magnesiumia kuin vaaleissa. Väriryhmien sisällä peitinkarvojen ja harjajouhien Na- 
ja K-pitoisuudet olivat samaa suuruusluokkaa. Mustissa ja ruskeissa harjajouhissa oli enemmän kaliumia ja natriumia kuin vaaleissa.

Harjajouhissa oli vähemmän rautaa verrattuna peitinkarvoihin. Väri ei vaikuttanut harjajouhien Fe-pitoisuuteen. Väriryhmien sisällä Zn-määrät olivat peitinkarvoissa ja harjajouhissa samaa suuruusluokkaa. Tummissa jouhissa oli keskimäärin vähemmän sinkkiä kuin vaaleissa.

Harjajouhissa oli enemmän kuparia kuin peitinkarvoissa. Vaaleissa harjajouhissa Cupitoisuus oli korkeampi kuin ruskeissa ja mustissa. Tummilla ja punaruunikoilla harjajouhien tuhkapitoisuus oli hiukan pienempi mutta ruudikoilla ja vaaleilla hiukan suurempi verrattuna peitinkarvaan vastaavasti. Tummissa harjajouhissa oli enemmän tuhkaa kuin vaaleissa.

Tom-Tom nimisen Welsch-cob pinto-tamman peitinkarvojen ja harjajouhien kivennäis- ja hivenainepitoisuudet olivat seuraavat:

\begin{tabular}{|c|c|c|c|c|c|c|c|c|c|}
\hline & & & ppm & & & & & & $\%$ \\
\hline & $\mathrm{Ca}$ & $\mathrm{Mg}$ & $\mathrm{Na}$ & $\mathrm{K}$ & $\mathrm{Zn}$ & $\mathrm{Fe}$ & $\mathrm{Cu}$ & Mn & Tuhkaa \\
\hline **Ruskea peitinkarva & 1164 & 308 & 165 & 267 & 172 & 74 & 17.3 & 15.9 & 1.00 \\
\hline$* *$ Valkea & 617 & 147 & 103 & 52 & 126 & 22 & 9.9 & 8.3 & 0.77 \\
\hline *Valkea & 100 & 124 & 45 & 20 & 136 & 70 & 11.0 & - & 0.19 \\
\hline${ }^{*}$ Musta harjajouhi & 137 & 292 & 66 & 77 & 140 & 36 & 13.7 & - & 0.48 \\
\hline *Valkea & 19 & 44 & 43 & 18 & 150 & 40 & 76.7 & - & 0.26 \\
\hline
\end{tabular}

**maaliskuu, *tammikuu

Yhdistelmästä käy ilmi, että samalla hevosella karvojen ja jouhien väri sekä näytteenottokuukausi vaikuttavat tuloksiin. Tom-Tomin ruskean peitinkarvan koostumus muistuttaa lähinnä ruunikoiden karvojen koostumusta (Taulukko 4); valkeiden peitinkarvojen ja jouhien koostumus muistuttaa vaaleiden hevosten vastaavia arvoja (Taulukot 2 ja 4), joskin vaaleiden jouhien Cu-pitoisuus ko. hevosella oli epätavallisen korkea. Tom-Tomin mustien harjajouhien koostumus taas muistuttaa tummien sekä ruunikkohevosten mustien jouhien koostumusta (Taulukko 5).

Puma-nimisen ruunikkoruunan harjajouhet olivat niin ohuet ettei niistä otettu esteettisistä syistä näytettä, vaan jouhinäyte otettiin hännästä. Analyysitulokset olivat seuraavat:

\begin{tabular}{|c|c|c|c|c|c|c|c|c|}
\hline & & & ppm & & & & & $\begin{array}{c}\% \\
\text { Tuhkaa }\end{array}$ \\
\hline & $\mathrm{Ca}$ & $\mathrm{Mg}$ & $\mathrm{Na}$ & $\mathrm{K}$ & $\mathrm{Zn}$ & $\mathrm{Fe}$ & $\mathrm{Cu}$ & Tuhk \\
\hline Ruskea peitinkarva & 757 & 291 & 101 & 46 & 142 & 27 & 12.3 & 0.58 \\
\hline Häntäjouhi & 200 & 645 & 371 & 443 & 172 & 149 & 34.3 & 1.29 \\
\hline
\end{tabular}

Kuten yhdistelmästä käy ilmi, ovat Puman häntäjouhien kivennäis- ja hivenainepitoisuudet olleet enimmäkseen selvästi korkeampia verrattuna tutkittujen hevosten harjajouhien koostumukseen (Taulukko 5).

\section{Tulosten tarkastelu}

Tutkimuksessa todettiin, että hevosten peitinkarvojen kivennäis- ja hivenainepitoisuudet vaihtelevat melko laajoissa rajoissa. Mikäli karva-analyysejä aiotaan käyttää kivennäis- ja hivenaineiden puutosten indikaattorina tulisi vertailuaineistoa olla niin paljon, että saataisiin selville kivennäis- ja hivenaineiden ns. frekvenssihajonnat väri- 
ryhmittäin ja vuodenajoittain. Tämän tutkimuksen aineisto on ko. tarkoitukseen liian suppea. Aineisto on kuitenkin ollut niin suuri, että värin ja vuodenajan vaikutuksia on saatu esiin. Lisäksi tutkimuksessa on käynyt ilmi, että harjajouhien koostumus poikkeaa olennaisesti peitinkarvan koostumuksesta.

KowNACKI (1962) on tutkinut puolalaisten hevosten peitinkarvojen kivennäis- ja hivenainepitoisuuksia, ja saanut seuraavia arvoja $\mathrm{Ca} 0.2-0.4 \%, \mathrm{Mg} 5-8 \%$, Na $0.1 \%-$ $0.3 \%$, K $0.3-1.9 \%$, Fe $0.1-0.2 \%$ ja Mn $0.0001-0.0002 \%$. Näistä arvoista vain Caja Mn-arvot ovat olleet samaa suuruusluokkaa mutta muut paljon korkeampia verrattuna tämän tutkimuksen tuloksiin. SIPPEL et al. (1964) määrittivät varsojen, siitostammojen ja oriiden karvoista Ca-, P-, Mg-, K-, Na-, Fe-, Cu-, Zn- ja Mn-pitoisuudet. Karvojen väri ei tutkimuksesta käy ilmi, mutta eläimet ovat luultavasti olleet pääasiassa raudioita ja ruunikoita. Heidän tutkimuksessaan kivennäis- ja hivenainepitoisuudet, lukuunottamatta Na-, K-, Cu- ja Mn-pitoisuuksia, ovat olleet samaa suuruusluokkaa kuin tässä tutkimuksessa (Taulukko 3). Karvojen tuhkapitoisuus (Taulukot 1-5) on ollut samaa suuruusluokkaa verrattuna Wysockm ja KLETTin (1971) saamiin arvoihin. SiPPELin et al. (1964) julkaisusta ei käy ilmi karvojen tuhkapitoisuutta.

$\mathrm{K}$ a lsium, fosfori ja magnesi um. Väri vaikutti erittäin selvästi peitinkarvojen Ca- ja Mg-pitoisuuksiin (Taulukko 3). Varsojen peitinkarvoista on löydetty enemmän kalsiumia ja fosforia kuin täyskasvuisten hevosten karvoista (SIPPEL et al. 1964). Wysockin ja KLETTin (1971) tutkimuksissa Shetlannin raudikko-ponivarsojen (ㅇ) peitinkarvojen keskimääräinen Ca-pitoisuus vaihteli talvikuukausina $1200-1910$ ppm:n välillä. Tässä tutkimuksessa raudikkohevosten peitinkarvojen Ca-pitoisuus vaihteli tammi- ja maaliskuussa 466 -916 ppm:n välillä ja Ca-pitoisuuden vuodenaikavaihtelut ovat olleet samansuuntaisia verrattuna SiPpeLin et al. (1964) saamiin tuloksiin.

Karvojen fosforipitoisuuksia ei tässä tutkimuksessa määritetty. SiPPEL et al. ovat löytäneet aivan pienten varsojen karvoista keskimäärin 993 ppm keväällä ja täyskasvuisten oriiden ja tammojen karvoista keskimäärin $350-540$ ppm fosforia eri vuodenaikoina. Wysockin ja KLetrin (1971) tutkimuksessa ponivarsojen karvojen P-pitoisuus vaihteli eri talvikuukausina keskimäärin $360-410 \mathrm{ppm}$ :n välillä. Kummassakaan tutkimuksessa karvojen P-pitoisuudessa ei havaittu selviä vuodenaikavaihteluita.

Tummissa karvoissa oli enemmän magnesiumia kuin vaaleissa (Taulukko 4). Syyskuussa kerätyissä karvoissa oli enemmän magnesiumia kuin muina vuodenaikoina (Taulukko 3). SipPELin et al. (1964) tutkimuksissa täysikasvuisten tammojen ja oriiden karvojen Mg-pitoisuus oli korkein syksyllä, joskin talvellakin tavattiin korkeita arvoja. KowNAcKin (1962) mukaan hevosen saama Mg-määrä vaikuttaa peitinkarvojen Mgpitoisuuteen, ja talvella karvoissa on enemmän magnesiumia kuin kesällä.

Na t ri u m ja ka li u m. Peitinkarvojen väri (Taulukko 4) ja vuodenaika (Taulukko 3) vaikuttivat karvojen Na- ja K-pitoisuuksiin. SiPPEL et al. (1964) löysivät karvoista korkeita Na- ja K-määriä talvella. Tässä tutkimuksessa alhaisimmat Na- ja Kmäärät tavattiin tammikuussa (Taulukko 3), mutta jo maaliskuussa tummien hevosten karvoissa olivat ko. aineiden pitoisuudet korkeat; vaaleilla hevosilla Na- ja K-pitoisuudet olivat korkeimmat syksyllä (Taulukko 2). SIPPELin et al. tutkimuksissa kevätkarvojen keskimääräinen Na-pitoisuus eri hevosryhmillä vaihteli 157-247 ppm:n, kesäkarvojen 196-321 ppm:n ja talvikarvojen $234-823$ ppm:n välillä. $\mathrm{K}$-arvojen vastaavat vaihtelut olivat $239-383$, 339-503 ja 725-1027 ppm. KownAckin (1962) mukaan heikoilla 
laitumilla pidettyjen työhevosten karvoissa on varsinkin talvella vähemmän natriumia ja kaliumia verrattuna normaalilla talliruokinnalla pidettyihin hevosiin. Hän suoritti tutkimuksensa Puolassa. Talviaikana ulkona pidetyille hevosille kasvaa pitempi karva kuin tallissa (varsinkin lämpöisessä) pidetyille hevosille. Tämän tutkimuksen hevoset pidettiin tallissa, jonka lämpötila oli talvella melko alhainen. Hevosten rehuistaan saamat Na- ja K-määrät ovat olleet varsin kohtuullisia, ja natriumia ne ovat saaneet talvella vain heinistä ja kauroista; keväällä ja kesällä noin puolet tutkituista hevosista sai heinien ja kaurojen lisäksi natriumkloridia suolakiven muodossa. Hevosista 6 oli $2-3$ viikkoa laitumella kesän aikana.

R a u t a ja sinkki. Peitinkarvojen Fe- ja Zn-pitoisuudet vaihtelivat samansuuntaisesti eri vuodenaikoina (Taulukko 3). SiPpelin et al. (1966) tutkimuksessa Fearvot olivat keväällä korkeampia kuin syksyllä ja talvella, kun taas Zn-arvot olivat varsinkin siitosoreilla keväällä pienempiä kuin muina vuodenaikoina. SIPPEL et al. arvelevat alhaisten Zn-määrien oreilla johtuvan siitä, että niitä oli käytetty runsaasti keväällä siitokseen. Karvojen Zn-pitoisuuden on todettu liittyvän mm. kilpirauhasaktiviteettiin (ref. Henning et al. 1969), esim. goitrogeenien anto alentaa sioilla harjasten Zn-pitoisuutta. Väri ei tässä tutkimuksessa vaikuttanut peitinkarvojen Fe- ja Zn-pitoisuuksiin. Toisaalta tummissa harjajouhissa oli sinkkiä vähemmän kuin vaaleissa (Taulukko 5).

$\mathrm{Ku}$ pari ja manga a ni. Peitinkarvojen Cu-ja Mn-pitoisuudet vaihtelivat eri vuodenaikoina (Taulukko 3). Cu-arvot olivat kesä-syyskuussa alhaisia. SIPPEL et al. (1964) löysivät karvoista syyskuussa vähemmän Cu:ta kuin keväällä. Heidän julkaisemansa Cu-arvot ovat olleet jonkinverran korkeampia verrattuna tämän tutkimuksen tuloksiin.

Mn-arvot olivat maaliskuussa korkeammat kuin kesäkuussa (Taulukko 3). SiPPELin et al. tutkimuksissa syys- ja talviarvot olivat korkeampia kuin kevätarvot. Heidän Mnarvonsa ovat olleet $2-4$ kertaa korkeampia verrattuna tämän tutkimuksen arvoihin. ANkEn et al. (1967) mukaan värillisen peitinkarvan Mn-pitoisuus on hyvä Mn-puutoksen indikaattori naudalla.

Värin vaikutus karvojen Mn-pitoisuuteen oli tässä tutkimuksessa melko selvä; tummemmilta hevosilta löydettiin korkeampia Mn-arvoja kuin vaaleilta. Kuparia löytyi eniten punaruunikoiden karvoista (Taulukko 4). Gossin ja GreEsin (1955) mukaan valkeassa hevosenkarvassa on enemmän kuparia (15 ppm) kuin mustassa (10 ppm). Tässä tutkimuksessa vaaleista harjajouhista löydettiin enemmän kuparia kuin ruskeista tai mustista (Taulukko 5).

Kasvuvaiheessa karvojen kivennäis- ja hivenainepitoisuudet riippuvat luultavasti ensikädessä ns. endogeenisistä tekijöistä, kuten karvojen väristä ts. karvojen pigmenttipitoisuutta säätelevistä tekijöistä (melatonin $=\mathrm{MSH}$ ), karvojen kasvurytmistä ja kasvua säätelevistä tekijöistä sekä eläimen kivennäis- ja hivenainetasapainosta. Myös eksogeeniset tekijät kuten hiki, tali, auringon valo sekä erilaiset kontaminaatiot (ulosteet, multa jne.) voivat vaikuttaa karvojen kivennäis- ja hivenainepitoisuuteen. Vielä ei tiedetä yksityiskohtaisesti, kuinka ja/tai missä määrin nämä eksogeeniset ainekset "fiksoituvat" karvan aineosiksi. On todettu kuitenkin, että karvoissa tapahtuu yllättävän nopeaa mineraalien vaihtoa. Hitaan karvankasvun aikana hevosille annettua $\mathrm{Ca}^{45}$ :ttä ja $\mathrm{P}^{32}$ :ta tavattiin karvoista tosin vasta kuukauden kuluttua (WYsocki ja KLETT 1971). Injektioitaessa suonensisäisesti lampaisiin $\mathrm{P}^{32}$ :ta radioaktiivisuus oli villassa korkein jo 48 tunnin jäl- 
keen, kun taas villarasvasta ei löydetty lainkaan $\mathrm{P}^{32}$ :ta (ANKE et al. 1971 b). Pantaessa naudan pötsiin $\mathrm{Mn}^{52}$ :ta löydettiin karvoista $48 \mathrm{t}: \mathrm{n}$ kuluttua merkittäviä määriä radioaktiivisuutta (ANKE et al. 1967). Mn-injektiot kohottivat nopeasti karvojen Mn-pitoisuutta hevosella (ref. SIPPEL et al. 1964). Samansuuntaisia havaintoja tehtiin annettaessa koe-eläimille $\mathrm{Mo}^{99}$ :ää (ANKE et al. 1971 a). Kuten naudalla, karva-analyysi voi ilmeisesti hevostenkin kohdalla muodostua hyväksi mineraalitasapainon indikaattoriksi, kunhan saadaan selvät normaaliarvot eri vuodenaikoja ja karvavärejä varten. Missä määrin tässä tutkimuksessa hevosten peitinkarvojen kivennäis- ja hivenainepitoisuudet ovat kuvastaneet riittävää mineraalien saantia tai mahdollisia puutteita on vaikea sanoa, koska ko. hevosilla suoritettujen ruokintatutkimusten tulosten käsittely on vielä kesken.

\section{Yhteenveto}

25:stä pääasiassa Tanskasta Suomeen tuotetusta puoliverihevosesta kerättiin peitinkarvanäytteitä maalis-, kesä-, syys- ja tammikuussa. Näytteistä määritettiin kalsium-, magnesium-, natrium-, kalium-, rauta-, sinkki-, kupari-, mangaani- ja tuhkapitoisuudet. Tammikuussa kerättiin peitinkarvojen ohella myös harjajouhinäytteet analysoitaviksi. Kationien määrityksessä käytettiin kuivapolttomenetelmää ja atomiabsorptiospektrofotometriaa.

Karvojen koostumuksessa ilmeni laajoja vaihteluita. Vuodenaika vaikutti selvästi kaikkien tutkittujen kivennäis- ja hivenaineiden pitoisuuksiin. Hevosten väri vaikutti selvästi karvojen Ca-, Mg-, Na-, K-, Cu- ja Mn- ja tuhkapitoisuuksiin. Tammikuussa kerättyjen peitinkarvojen ja harjajouhien koostumuksessa todettiin selviä eroja; peitinkarvojen Ca-, Fe- ja tuhkapitoisuudet olivat korkeammat mutta Na- ja Cu-pitoisuudet pienemmät verrattuna harjajouhiin. Väri vaikutti harjajouhien koostumukseen; mustissa harjajouhissa Ca-, Mg-, Na-, K- ja tuhkapitoisuudet olivat korkeammat mutta $\mathrm{Zn}$ ja Cu-pitoisuudet alemmat kuin vaaleissa harjajouhissa.

\section{KIRJALLISUUS}

ANKE, M. 1965. Der Mengen- und Spurenelementgehalt des Rinderhaares als Indikator der Calcium-, Magnesium-, Phosphor-, Kalium-, Natrium-, Eisen-, Zink-, Mangan-, Kupfer-, Molybdän- und Kobaltversorgung. 1. Mitt. Das Reinigen des Haares. Arch. Tierernähr. 15, 6:461-468.

ANKE M. 1971. Der Haartest zur Diagnose von Mineralstoffmangelerscheinungen. Monatshefte für Vet. Med. 26, 12:445-449.

Anke, M., Dietrrich, M., Hoffmann, G. \& Jeroh, H. 1967. Der Mengen- und Spurenelementgehalt des Rinderhaares als Indikator der Calcium-, Kupfer-, Molybdän- und Kobaltversorgung. 6. Mitt. Der Ein- und Ausbau von oral verabreichtem Mangan-52 in das Haar, das Blut und die Milch des Rindes. Arch. Tierernähr. 17, 1-2:81-86.

Anke, M., Henning, A., Diettrich, M., Hoffmann, G., Wicke, G. \& Pflug, D. 1971 a. Resorption, Exkretion und Vertailung von ${ }^{99}$ Molybdän nach oraler Gabe an laktierende Wiederkäuer. Arch. Tierernähr. 21:505-513.

Anke, M., Henning, A., Hoffmann, G., Wicke, G., Pflug, D., Schüler, D., Gruber, G. \& Kleemann, J. 1971b. Der Mengen- und Spurenelementgehalt des Haares als Indikator der Mineralstoffver- 
sorgung. 7. Mitt. Der Ein- und Ausbau von ${ }^{32}$ Phosphor in Wolle und Wollfett des Schafes. Arch. Tierernähr. 21:129-132.

Goss, H. \& Green, M. M. 1955. Copper in hair. Science 122:330.

Henning, A., Martin, J., Anke, M. \& Schüleer, D. 1969. Die Parakeratose des Schweines. 4. Mitt. Methylthiouracil als Parakeratosenoxe. Arch. Exp. Vet Med. 23:911-920.

KowNAcKI, M. 1962. Estimation of the supply of minerals to horses based on values in horny tissue of the rounded hoof and in the hair. Roczniki Nauk Rolniczych (B) 80:519.

O'Mary, C. C., Bell, M. C., SNeEd, N. N. \& Butrs, Jr., W. T. 1970. Influence of ration copper on minerals in the hair of Hereford and Holstein calves. J. Anim. Sci. 31:626-630.

Sippel, W. L., Flowers, J., O'Farrell, J., Thomas, W. \& Powers, J. 1964. Nutrition consultation in horses by aid of feed, blood and hair analysis. Proc. Amer. Ass. of Equine Practioners 139-152.

WYsocki, A. A. \& KLETT, R. H. 1971. Hair as an indicator of the calcium and phosphorus status of ponies. J. Anim. Sci. 32:74-78. 